\title{
A World of
}

Quality Scholarship.

International Relations Journals

from Cambridge University Press

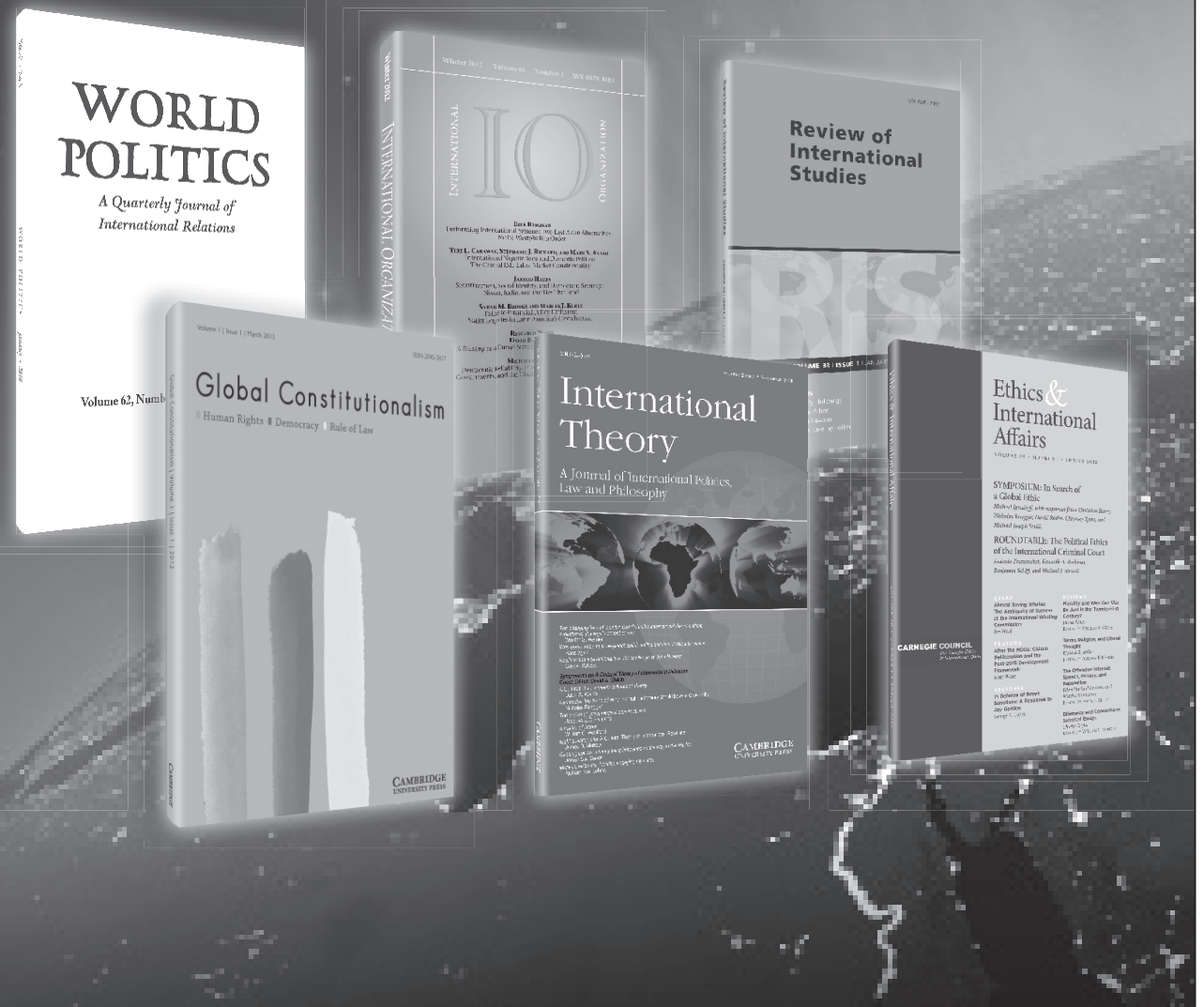

journals.cambridge.org/ir 


\section{Publishing 10 issues a year from 2014}

Ageing \& Society

Published for the Centre for Policy on Ageing and the British Society of Gerontology

\section{Editor}

Christina R. Victor, Brunel University, UK

Ageing \& Society is an inter-disciplinary and international journal devoted to the understanding of human ageing and the circumstances of older people in their social and cultural contexts. It draws contributions and has readers from many academic social science disciplines, and from clinical medicine and the humanities. In addition to original articles, Ageing \& Society publishes book reviews, occasional review articles and special issues.

Ageing \& Society has now moved to online submissions. The entire review process is now being conducted through the Manuscript Central platform, including revisions and editorial assessments. If you wish to submit a paper to the journal please do so via the website.

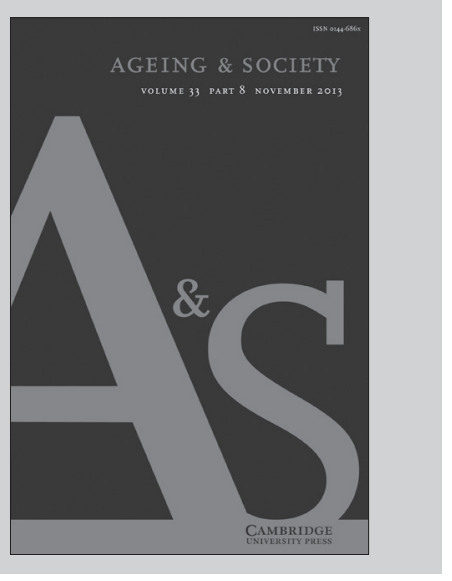

Ageing \& Society is available online at: http://journals.cambridge.org/aso

To subscribe contact Customer Services

in Cambridge:

Phone $+44(0) 1223326070$

$\mathrm{Fax}+44(0) 1223325150$

Email journals@cambridge.org

in New York:

Phone (845) 3537500

Fax (845) 3534141

Email

subscriptions_newyork@cambridge.org

\section{Free email alerts}

Keep up-to-date with new material - sign up at

journals.cambridge.org/register 


\section{Canadian Journal on Aging / La Revue canadienne du vieillissement}

Published on behalf of the Canadian Association on Gerontology/ L'Association canadienne de gérontolgie

\section{Editor-in-Chief}

Margaret J. Penning, University of Victoria, Canada

This journal disseminates the latest work of researchers in the social and biological sciences who study the older population of Canada and other countries; informs policy debates relevant to aging; seeks to improve the quality of life for Canada's older population and for older populations in other parts of the world through the publication of research that focuses on the broad range of relevant issues; and encourages the exchange of the latest ideas in gerontological research.

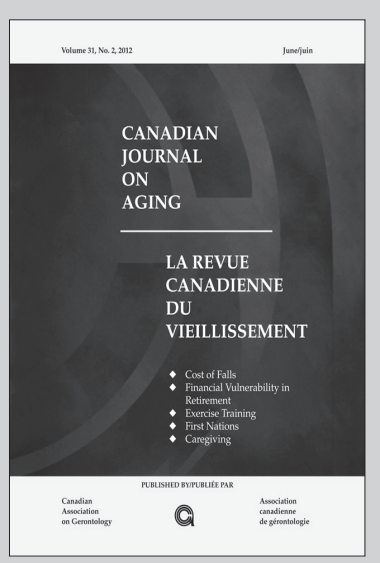

Canadian Journal on Aging / La Revue canadienne du vieillissement

is available online at:

http://journals.cambridge.org/cjg

To subscribe contact

Customer Services

in Cambridge:

Phone +44 (0)1223 326070

Fax +44 (0)1223 325150

Email journals@cambridge.org

in New York:

Phone +1 (845) 3537500

Fax +1 (845) 3534141

Email

subscriptions_newyork@cambridge.org

\section{Free email alerts}

Keep up-to-date with new material - sign up at

journals.cambridge.org/register 


\section{Du Bois Review: \\ Social Science Research on Race}

Published for the W.E.B. Du Bois Institute for African and African American Research, Harvard University

\section{Editors}

Lawrence D. Bobo, Harvard University, USA

Michael C. Dawson, University of Chicago, USA

Du Bois Review: Social Science Research on Race $(D B R)$ is an innovative periodical that presents and analyzes the best cutting-edge research on race from the social sciences. It provides a forum for discussion and increased understanding of race and society from a range of disciplines, including but not limited to economics, political science, sociology, anthropology, law, communications, public policy, psychology, and history. Each issue of $D B R$ opens with remarks from the editors concerning the three subsequent and substantive sections: STATE OF THE DISCIPLINE, where broad-gauge essays and provocative think-pieces appear; STATE OF THE ART, dedicated to observations and analyses of empirical research; and STATE OF THE DISCOURSE, featuring expansive book reviews, special feature essays, and occasionally debates. Many issues also now include a conversation between Professor Henry Louis Gates, Jr. and an eminent scholar on broad areas of research regarding race.

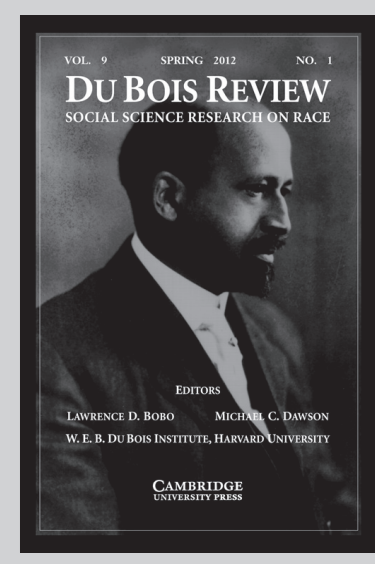

\section{Du Bois Review: Social Science} Research on Race

is available online at:

http://journals.cambridge.org/dbr

To subscribe contact

Customer Services

in Cambridge:

Phone +44 (0)1223 326070

Fax +44 (0)1223 325150

Email journals@cambridge.org

in New York:

Phone +1 (845) 3537500

Fax +1 (845) 3534141

Email

subscriptions_newyork@cambridge.org

\section{Free email alerts}

Keep up-to-date with new material - sign up at

journals.cambridge.org/register 


\section{Journal of Social Policy}

\section{Notes for Contributors}

Notes for contributors can be downloaded from the journal's website: journals.cambridge.org/jsp

\section{The Social Policy Association}

The Social Policy Association supports the study of all aspects of Social Policy and Administration through the sponsorship of the Journal of Social Policy and Social Policy and Society, the publication of a newsletter, the organisation of an annual conference and a small grants scheme. It represents its members through contact with a range of bodies, including the ESRC. For further information about the activities of the SPA, contact: Rachael Dobson, School of Psychology, Criminology and Sociology, Faculty of Arts and Social Sciences, Kingston University, Penrhyn Road Campus, Kingston upon Thames, Surrey KT1 2EE. The SPA website is at: www.socialpolicy.org.uk. 


\section{Articles}

\section{Philip Taylor and Catherine Earl}

The Social Construction of Retirement and Evolving Policy Discourse of Working Longer - CORRIGENDUM

Jo Blanden and Lindsey Macmillan

Educational Inequality, Educational Expansion and Intergenerational Mobility $\quad 589$

Jo Blanden and Lindsey Macmillan

Educational Inequality, Educational Expansion and Intergenerational Mobility - CORRIGENDUM

Jurgen De Wispelaere

Basic Income in Our Time: Improving Political Prospects Through Policy Learning?

Noorseha Ayob, Simon Teasdale and Kylie Fagan

How Social Innovation 'Came to Be': Tracing the Evolution of

a Contested Concept

Liv Zetterberg, Urban Markström and Stefan Sjöström

Translating Coercion Policy into Inter-Organisational Collaboration-the

Implementation of Compulsory Community Care for People with Mental IIIness 655

Kirsty Strokosch and Stephen P. Osborne

Asylum Seekers and the Co-production of Public Services: Understanding the Implications for Social Inclusion and Citizenship

Isabel Shutes

Work-related Conditionality and the Access to Social Benefits of

National Citizens, EU and Non-EU Citizens

Eric Breit, Tone Alm Andreassen and Robert H. Salomon

Modification of Public Policies by Street-Level Organisations: An Institutional Work Perspective

Valerie Egdell, Matthew Dutton and Ronald Mcquaid

Third Sector Experiences of Work Programme Delivery

\section{Patricia Frericks, Julia Höppner and Ralf Och}

Institutional Individualisation? The Family in European Social Security

Institutions

Book Reviews

Cambridge Journals Online

For further information about this journal please go to the journal website at: journals.cambridge.org/JSP

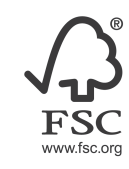

CAMBRIDGE UNIVERSITY PRESS 